\title{
Manuel Sacristán at the Onset of Ecological Marxism after Stalinism
}

\author{
Enric Tello \\ Department of Economic History, Institutions, Policy and World Economy, Faculty of \\ Economics and Business, University of Barcelona, Barcelona, Spain
}

\section{Introduction}

Thirty-one years ago, in 1985, Manuel Sacristán died in Barcelona at the age of 59. After the publication in 2014 of a volume with some of his writings translated into English (Llorente 2014), it is time to help non-Spanish-speaking readers to know more about him. Yet it is not easy to explain to generations born after the fall of the Berlin Wall in 1989 that Manuel Sacristán was a most important Marxist philosopher and at the same time one of the few pioneers introducing political ecology and antinuclear peace movement during the last quarter of the 20th century in Spain. Many people believe that Marxism, environmentalism and pacifism are views that exclude each other. Most of what has been said and done on behalf of Marxism since Stalin took over the leadership of the Communist Party of the USSR in the 1930s, up to its dissolution in 1991, contributes to sustaining this belief. The fast industrialization of the Old Russian Empire undertaken by the Soviet State was nowhere near taking into account ecological sustainability. Its socio-environmental impact turned out to be comparable or even worse than the ones caused by capitalist industrialization.

\section{Environmentalists and Marxists from the 1970s Onwards in Barcelona}

Sacristán began reflecting about political ecology from a Marxist standpoint when most of the world's left still disdained this view-social-democrats as well as orthodox communists. He did this in a place where it was least expected-in a Spain still under Franco's dictatorship where he was involved in the underground fight for freedom and a different kind of socialism. Thirty years after his death it is time to rescue Manuel Sacristán from oblivion and consider him one of the first postStalinist Ecological Marxists in Europe alongside Gorz (1975), Bahro (1977), Harich (1977), following in the steps of some earlier proponents of ecosocialist approaches like Barry Commoner, René Dumont or Robert Jungk, and ecofeminist ones like d'Eaubonne ([1978] 2000).

After having debated on how to politically respond to the economic crisis of the 1970s (Lacalle, Martínez Alier, and Sacristán 1978), Joan Martínez Alier and Manuel Sacristán took the lead in introducing environmentalism in Spain together with economist José Manuel Naredo and a small group of ecologists and epidemiologists. In 1979 the Antinuclear Committee of Catalonia, of which Sacristán was a founding member, held in a seminar on the energy crisis in capitalist society at the Faculty of Economics of the University of Barcelona. It opened with a lecture by Martínez Alier (1980) on energy and agrarian economics. Sacristán closed it with a lecture on "Why Does the Environmentalist Movement Lack Economists?" (1987), pointing to the methodological inhibitions of mainstream economics to take environmental factors into account. Seen in retrospect, an ironic situation took place. On one hand, Sacristán wondered why there were no economists in the environmentalist movement though he had Martínez Alier as a guest speaker, who was then writing his well-known book Ecological Economics (1982, 1984, 1987a). On the other hand, Martínez Alier also wondered why there was no ecological Marxism, criticizing the general reliance of Marx's followers on the "growth of productive forces" as a lever to attain socialism, having in front Sacristán who was then developing a Marxist political ecology. At that time Martínez Alier still regarded Marxism as a current without any bonds with political ecology due to its "adherence to the bourgeois ideology of progress based on the growth myth" (1984, 264-265). Together with José Manuel Naredo, he brought to light the disagreement of Engels and Marx with the energy analysis put forward by Sergei Podolinsky in 1880-1883 (Martínez Alier and Naredo 1982).

Later on Martínez Alier (1991, 318-319) became more open toward ecological Marxism. He dedicated the 1991 Spanish edition of his book to the memory of Manuel Sacristán, among others. Yet he considered Capitalism Nature Socialism, founded in 1988 by James O'Connor, to be the first international journal of ecological socialism. Dates are important: CNS began one year before the 
fall of the Berlin Wall; Manuel Sacristán had founded the ecosocialist and feminist journal Mientras Tanto (that alternated red, green and violet covers every three issues) in 1979, when his pioneering ecological Marxism already had a run for some years. Martinez Alier himself published several articles in Mientras Tanto (1985a, 1985b, 1987b, 1988; Martínez Alier and Galindo 1988), which was also the earliest Spanish journal to pay attention to the birth of the German Greens (Pérez 1980) and to publish the first European Ecosocialist Manifesto (Antunes et al. 1990). In 1992 Martínez Alier considered Sacristán a founder of ecological Marxism, while wondering whether it had not appeared "far too late and far too scant" (1992), and proposed to CNS to publish his second article translated into English (Sacristán 1992). The first one had been requested of him and published by Edward P. Thompson (Sacristán 1986).

More recently, the authors of the second Ecosocialist Manifesto (Kovel and Löwy 2001) have recognized Manuel Sacristán and his Spanish followers among the leading members of this current (Löwy 2013). Indeed, Sacristán started to reorient Marxism toward political ecology between 1968 and 1973, just after the invasion of Czechoslovakia by the USSR army to crush Alexander Dubček's attempt to overcome the Stalinist regime, and event that led Sacristán to resign from all his positions in the leadership of the Spanish Communist Party (PCE) and the Catalan PSUC. While he remained engaged with the base of the PSUC up to 1979, Sacristán proposed to a Spanish editor as early as 1972 to publish a new collection of books focused on what he then named socio-physics-meaning a socio-metabolic approach to nature-society interaction (López Arnal and Mir García 2015, 494).

This story about environmentalists and Marxists in Barcelona in the 1970s invites us to go deeper into the following questions (Tello 2003, 2007; Martínez Alier 2007): What were the main features of Manuel Sacristán's Ecological Marxism? And why did he take the direction toward a Marxist political ecology in the way he did, and where he did?

\title{
The Journals Materiales and Mientras Tanto
}

In the first issue of the journal Mientras Tanto Sacristán proclaimed that Owing to the way we have finally learned to look at the earth, we know that the agent cannot regard "liberating society's forces of production," supposedly fettered by capitalism, as a fundamental task. We have ceased to give credence to the mystical coincidence between society's objective development and communist objectives, a correspondence in which Lenin, for example, still believed. Now we know that we must earn the new Earth entirely with the work of our hands (Llorente 2014, 191). He added that

\begin{abstract}
the necessary revision of our conception of the revolutionary subject in industrial societies must not base workers' class consciousness solely on the negativity which a part of that class has overcome in those societies, thanks to struggle and the evolution of the system; it must also be based on the positivity of its status as sustainer of the species, conserver of life and indispensable organ of society's metabolism with nature. (Llorente 2014, 193)
\end{abstract}

The first editorial of Mientras Tanto overtly recognized that "those who live from their hands have been themselves far too dazzled by the rich, by the ones who destroy the Earth." It proclaimed that the goal was to attain "a fair humankind on an liveable Earth, rather than a huge flock of morons living in a noisy chemical, pharmaceutical and radioactive dung heap." The task lying ahead "could be undertaken in many ways depending on the place":

It consists for example in getting that environmentalist movements, which are the bearers of the selfcritical science of this turn of the century, endow themselves with political revolutionary capacity. It also consists as another example that feminist movements, by reaching the main outcome of the specific, universally human dimension of their contents, decide to fuse their emancipating power with the rest of freedom forces. Or it consists that the classic revolutionary organizations may understand that their capacity to work for a fair and free humankind has to be purified and confirmed by means of the self-criticism of the old social knowledge that shaped their birth. (Sacristán 1987, 189-195)

In a press interview after the first demonstration against nuclear power plants in Barcelona in 1979, Sacristán proclaimed that "socialism faces disaster unless it assimilates the new ecologicalrevolutionary motives and, in turn, these new motives should assimilate and understand that a social revolution is necessary" (Fernández Buey and López Arnal 2004, 115-125). In an interview in the 
Mexican journal Dialéctica published in 1983 he summed up the ecosocialist task of Mientras Tanto:

\begin{abstract}
At the forefront, in the centre of the things I am doing-not just me but an entire collective-is the journal Mientras Tanto, with which we are trying, very modestly (since we have never sold more than 3,500 copies of an issue), to prepare the way for thinking, from a socialist point of view, about new problems of contemporary civilisation. Problems unforeseen-and perhaps unforeseeable-by the classic authors, and caused by the development of some modern productive-destructive forces, particularly technological forces. (Llorente 2014, 261)
\end{abstract}

Mientras Tanto had been preceded in 1977-1978 by another journal called Materiales, also founded by Sacristán. It published Rudolf Bahro's criticism of the so-called real socialism in East Germany; it translated into Spanish a discussion about James O'Connor's influential book on The Fiscal Crisis of the State (Bay Area Group 1978); and unveiled in Spain two significant ecosocialist authors: Wolgang Harich and Barry Commoner. Sacristán appreciated Harich's works on literature and politics, and knew of his situation as a dissident Marxist sentenced in East Germany to ten years imprisonment in 1957 for his criticisms of military repression against the 1956 revolts in Hungary and Poland. He was immediately interested in Harich's controversial book Communism Without Growth? (Harich 1977), stressing the fact that "any communist who sees the ecological problem to be the basic reference of today's problems of revolution (as in Harich's case) is compelled to revise the notion of communism" (Sacristán 1985, 227). Yet Sacristán was in sharp disagreement with the authoritarian outlook which Harich assumed to be unavoidable if human needs were going to be satisfied in an egalitarian manner while stopping the growth of the productive-destructive forces. If recognition of the ecological crisis led Harich, an anti-Stalinist dissident, to "do away with the freedom element and compensate its loss increasing the egalitarian one," Sacristan's option was approaching the problem of political power with a more Gandhian-like, federal and freer outlook. As he polemically said in a public debate with Harich held in Barcelona in 1979:

What becomes relevant is the assimilation of a strategic conception which was scorned under the tag of Gandhism. It is time to speak clearly, by calling a spade a spade, especially at this stage of the twentieth century. If we stick to the industrial countries...it's time or even late to admit that the revolutionary capacity, qualitatively transforming, of the staunch traditions of the workers movement has been scant. To state it rather provocatively; it is hard to see that the III International has accomplished its doctrinal goals more than Gandhism did with theirs. Even more, profiting from the experiences which for the sake of brevity I am calling Gandhism may contribute to shape the necessary revision of revolutionary concepts in a way that may add to them a radical alternative awareness. (Sacristán 1981, 38-39)

In his prologue to Harich's book Sacristán (1985, 211-231) referred to the socialist undercurrents that

in the last five years...have agreed to revise the way or rather the measure by which classic Marxists regarded certain characteristics as simple data, especially the unlimited growth of the material productive forces, the Ricardian production for the sake of production in which Marx at one moment saw the basic dynamics of freedom.

He specifically pointed to "the writers of the Marxist section of the journal Science for the People," and it is worth mentioning that in 1978 Materiales published an article by Barry Commoner on "President Carter's Energy Plan: Our Bleak Future" (Sacristán 1984, 221). It is likely that his early readings of Barry Commoner's Science and Survival (1970, translated into Spanish in 1975), and of The Closing Circle (1971 and 1973 respectively), helped Sacristán to frame the ecological crisis as a key socialist issue. Sacristán's personal concern for the environment was previous to any political commitment. It most probably came from his keen interest on hiking, as well as from his love of cultures and struggles of the American hunting-gathering First Nations-such as the ones of Geronimo (Goyaałé) and the Mescalero-Chiricahua Apaches he translated and edited (Barrett 1906; Capella 2005, 180-183). In a biography of Sacristán, Juan-Ramón Capella reproduces an introspective thought of his fieldwork notes of a hike in 1973 about the attraction he felt for peasant labor: 
I think I finally know where lies the root of their traits that make me finding them more pleasing than the capitalist producers (including workers and even more employees): gatherers, herders and farmers directly act for the sustenance and shelter. That's not the case of the industrial producer... What I think disgusting is abstract labour. $(2005,179)$

In the same vein, his wife Giulia Adinolfi (1980) argued that as long as domestic labor was caringrelated, affection-embedded and non-commodified, it was also superior to commodified labor.

\section{From Productive to Productive-Destructive Forces}

Sacristán never discussed with Martínez Alier Engels' refusal to adopt Podolinsky's proposal to formulate the Marxian approach to labor force in terms of energy, or the uncritical progressivist mood of the orthodox Marxist approach to the growth of productive forces. He most likely knew about Sergei Podolinsky from Martínez Alier, and he had no doubts of the need to reconsider these key aspects within Marxist tradition. What he actually did was to take a small analytical step which involved a radical political rethinking. He brought to the fore the intrinsic ambiguity of these productive forces which are, and have always been, also destructive from an ecological point of view. Sacristán started to talk about "productive-destructive forces" and adopted all the consequences that this meant from a Marxist political ecology (Llorente 2014, 262-265):

I believe that the Marxian model of the role of the forces of production in social change is correct....and plausible on a historical, empirical level. So, I don't think it's necessary to revise those theses...The new development is the fact that we now have reasons to suspect that the social change at whose gates we stand is not necessarily going to be liberating merely because of the effect of this dynamics...We have no guarantee that the tension between the forces of production-destruction and the relations of production that exist today must give rise to emancipatory prospects. The very opposite could also occur.

Hence, he stressed "the problematic situation that the efficacy of the developing productivedestructive forces poses for a socialist perspective today": The problem is how to react politically when faced with the present tension between the developing productive-destructive forces and the existing relations of production. And I think the main part of an adequate solution consists in distancing oneself from a simplistic response based on an unshakeable faith in the emancipatory direction of the development of the productivedestructive forces.

When an interviewer asked him whether this meant reaching the limits of Marxian thought, he answered: "I don't think Marx's last word on all the questions that we are discussing is entirely clear...Marx died without completing his ideas, without attaining peace with himself." He added that "his life coincided with an important transition in scientific knowledge," and pointed to Marx's late correspondence with the Neo-populist Vera Zasulich about the role of the Russian village community on the road to socialism, his objections to the introduction of railroads into the Rhine's tributary valleys, together with his doubts and silences regarding Podolinsky's proposal (Llorente 2014, 267-268):

I admit that such reflections from the late Marx...have opened up for me the possibility of thinking that there is no contradiction between maintaining the Marxian model with regard to the effect of the development of the productive-destructive forces and their clash with the relations of production, and a socialist political conception that...conceives the function of socialist management- to say nothing of communal managementas the administration of those forces, and not as a simply removal of the fetters that the current relations of production impose upon them. I think that once it has been formulated in those terms, it turns out to be obviously consistent with the idea of a socialist society, with a regulated society.

\section{Why Marx's Ecological Inklings were so Long set Aside?}

To what extent did Sacristan's approach to the gap between Marxism and political ecology only precede, and to what extent did it differ from the more recent one adopted by John Bellamy Foster and Paul Burkett in regard to the Podolinsky affair? Foster (2000) argues that the notion of social metabolism constitutes one of Marx's major intellectual achievements. Even today one is struck when reading at the end of chapter 15 of Capital (Marx 1996, 505-508) that, according to Marx, capitalism hampers the metabolic exchange with nature by preventing soil replenishment of nutrients 
removed by food and fibers growing on it, thus depleting its fertility. He then linked soil mining to the health degradation of industrial and agricultural workers, considering them as outcomes of the dynamics of capitalist productive forces that undermine the conditions for a long-lasting (we now say sustainable) metabolic exchange with nature (Engel-Di Mauro 2014).

From this ecological insight Marx drew the political conclusion that in a communist future the associated producers had to purposely restore again a lasting metabolism with nature as a regulatory law of social production in a way addressed to achieve full human development. This was one of the few occasions on which he allowed himself to break the self-imposed restraint of talking in a concrete manner about how a future socialist society would be, or what tasks it would carry out. On several of these occasions Marx defined communism as a way to establish a conscious regulation of societal metabolism aimed at achieving human development with the least energy expenditure. Yet Foster's and Burkett's enthusiasm for having recovered these brilliant ecological inklings of Marx may have led them to skip over several awkward questions. Namely, why did later Marxian currents never give any political importance to those inklings over a century after Marx's death in 1883 ? Furthermore, if ecology was so central to his idea of the task a communist society should undertake, why was Marx so full of doubts in the last years of his life, and in particular about how to answer to Sergei Podolinsky's proposal ([1880-1883] 2008)? Why did Engels answer with an outright denial? According to Foster and Burkett, there was nothing to be answered because the articles published by Podolinsky were incoherent, and all that had to be said on the subject was already in the writings of Marx and Engels (Foster 2000; Foster and Burkett 2004, 2008a, 2008b; Burkett and Foster 2006).

It is undeniable that Marx's work included, as philosophical background, a deeper ecological basis than any other economist of the time-which, together with the socialist-oriented aim of Sergei Podolinsky, helps to explain why he addressed the proposal to Marx and Engels and not, for instance, to the neoclassical economist William Stanley Jevons who had published The Coal Question in 1865. It is also true that Podolinsky's energy essay on the role of human labor in the socio-metabolic interchange with nature was still tentative and immature. For instance, Podolinsky's idea of human labor as a Carnot's "perfect machine" was undoubtedly misleading-he was most likely searching for some idea of "negentropy" before Schrödinger, Prigogine, Margalef, Passet, Morowitz and the like. But along with these shortcomings came his essay's many brilliant insights. In 1924 Vernadsky $(2007,212)$ praised it precisely because of its having stressed the thermodynamic differences between living and inert matter, and contributing to the foundations of the energetics of life. Podolinsky's idea of the capacity of human labor to temporarily increase non-dissipative energy storage in the biosphere is particularly pertinent to understanding agro-ecosystems (Ho and Ulanowicz 2005; Marull et al. 2016). Indeed, energy analysis is a subject that still remains methodologically debated and partially unsolved in ecological economics 130 years later (Giampietro, Mayumi, and Sorman 2012; González de Molina and Toledo 2014; Tello et al. 2016).

Foster and Burkett have done a good job revising the four versions of Podolinsky's essay (2008) and pointing out its flaws. But they have omitted other powerful insights of his article, as well as the shortcomings that existed in Engels' and Marx's texts; Marx and Engels did not grasp the difference between renewable and fossil energy (Tanuro 2010), just to mention one of the issues that Foster and Burkett criticize in Podolinsky as well. This lack of equanimity prevents them from arriving at a fair historiographical assessment. What really matters is that Podolinsky had already proposed turning Marx's approach to the metabolic interaction of human labor with nature into an operative and quantitative analysis. His attempt failed owing to Marx's death and Engels' final refusal. This entailed that the issue would remain at a very general and un-operative philosophical level within Marxism, precluding a serious take-off of ecosocialist research aimed to analytically develop the ecological inklings of Marx-which could also have helped to overcome the flaws in Podolinsky's work. Hence, Martínez Alier and Naredo (1982) were right in pointing out that Engel's refusal was a missed opportunity for starting an ecosocialist current a century earlier than it actually happened. The only "obituary" that deserves to be explained is this failure. From the end of the 19th century onwards most Marxists kept repeating again and again what Marx and Engels wrote, which precisely because of that remained undeveloped. Even worse, with only very few exceptions they ignored Marx's ecological and energy-related inklings throughout the whole historical period that saw the 
foundation and the fall of the USSR and the so-called real socialism in the Eastern bloc, as well as the so-called welfare state in the Western bloc.

Sacristan's way of reading Marx and Engels may be of some help in overcoming the propensity of some types of Marxism to remain locked within what Marx and Engels said in the 19th centurythus stifling the much needed fresh research on a crucial subject that is now at the core of the global crisis of capitalist civilization:

\begin{abstract}
I think that one finds the rational route for interpreting Marx's work if, to begin with, one abandons the apologetic urge and studies Marx against the backdrop of his time, which can be done knowing that there is, first, an aspect of Marx's work as timeless as the New Testament or Garcilasos's poetry, which is his work as philosopher of socialism, as a formulator or elucidator of socialist values. And secondly, if one breaks away from the remnants of what we might call Zhdanovism or Lysenkoism, and stops confusing the question of the origin of a cultural product-in this case, contemporary philosophy of science-with the question of its validity...If those two prejudices....are overcome, one is no longer a hostage of the dilemma between glorifying Marx's supposedly purely scientific literal meaning and an impassioned rejection of his work when one discovers that not all of it-far from itfulfils the formal requirement of science today. (Llorente 2014, 274)
\end{abstract}

Besides studying the works of Marxist classics, Sacristán was also very interested in following the first stirrings of ecological economics. When commenting on Boulding's (1978) Ecodynamics and Georgescu-Roegen's (1971) The Entropy Law and the Economic Process, he pointed out that

what tends to be imposed on economics is a greater focus on real processes and flows, which, by the way, doesn't fit very much with the dominant approaches among economists...The desirable assimilation of physical and biological concepts by economics is likely to give rise to a reconstruction of the theory on the basis of the ecological-economic reality of our species; a theory which, for example, may not go on working so cheerfully with concepts such as growth, or with such a mythological concept of equilibrium. (Sacristán 1984, 453-467)

This lack of attention toward biophysical flows and socio-ecological functioning led Sacristán to wonder about the methodological inhibitions undergone by the two opposed traditions of economic and political thought: Liberal mainstream economics, and Marxism as well.

\title{
Marx's Methodological Inhibitions Stemming from Hegel
}

The article on "Political Ecological Considerations in Marx" published in Mientras Tanto in 1984, and translated into English by CNS in 1992, is aimed at understanding why Marx's ecological inklings remained culturally forgotten and politically discarded over the span of a century. Sacristán identified that barrier in the Hegelian roots of Marx's way of thinking. For example, when commenting on the texts on the metabolic rift opened up by capitalist agriculture he says (Llorente 2014, 184-185):

\begin{abstract}
Marx's thinking here is interesting in that it does not fit in well with his usual train of thought...Marx's writings contain considerations (more than mere indications) that go beyond the ecology of labor under capitalism. But, in addition, Marx tried to use these ideas to understand what socialist society would be like...He starts with the very pessimistic conviction that capitalism will have completely destroyed the correct relationship between the human species and the rest of nature by the time socialism is to be constructed, understanding the word "correct" in a pragmatic sense, the appropriate relationship for the sustenance of the species. He then assigns to society the task of "systematically producing" this exchange between the human species and the rest of nature...Socialist society thus is characterized as that which establishes the ecological viability of the species.
\end{abstract}

Sacristán went on explaining how Marx, influenced by Hegel, adopted a deepseated pessimism in front of this global ecological destruction, accepting that history moves blindly along its bad side (Llorente 2014, 185-186):

Why is that such a categorical and stimulating text was not followed up on, given that it expresses the hypothesis that capitalism will not extinguish itself until it has entirely destroyed the lasting metabolism between the human species and nature?... One of the reasons for this lack of interest is 
probably found in the Hegelian philosophical base beneath Marx's thought. From Hegel, Marx inherited a peculiarly deterministic mode of thinking based on the idea that events are produced with internal logic and with absolute necessity, the idea that there is no distinction between the logical and the empirical, that facts are in and of themselves logically necessary. This is what he meant in the famous and oft-repeated phrase: "All that is real is rational." In addition, the logic or necessity that Hegelian philosophy attributes to events, to history, operates through negativity: it constructs a dynamic in which the motor of change, the motor of the historical process, is what Hegelians call "negation."

Thereby, according to Sacristán the underlying methodological inhibition that Marx and his followers felt when facing the ecological insight of capitalist ecological destruction lay in the deeply rooted Hegelian foundations of their own philosophical way of thinking. In other words, the same inhibitions which led to the refusal of Podolinky's proposal prevented Marx and Engels from pursuing their own socio-ecological forecast. Doing this would have entailed overcoming the Hegelian determinist view of History.

Hegel was paramount throughout Karl Marx's and Friedrich Engels' intellectual itineraries. It is widely acknowledged that it was through Hegel that they managed to turn the mechanical materialism coming from Epicurus into a historical materialism (Foster 2000). Indeed, it is worth wondering how such a peculiar grafting of Hegel's dialectics with materialist traditions turned out to be so productive for Marxist historiography. In 1959 Sacristán addressed the issue when commenting Marx's writings on Spain:

The working method applied by Marx in these articles could...be codified in the following rule: When explaining a political phenomenon, proceed in such a way that the analysis exhausts all superstructural instances before resorting to the fundamental socio-economic ones. This prevents them from becoming Dei ex machina devoid of a proper heuristic function. (Sacristán 1983, 9-23)

All the well-known Marxist historians have followed the same rule. This helps us to understand why Marx never overstepped the limits of his own Hegelian philosophical roots, the same ones that set a barrier to his intellectual and political advances toward political ecology. Yet one thing was Marx's way of thinking, and another what happened to his followers. The Hegelian blockage remained a barrier for them:

Generations upon generations of Marxists and Marxologists have read these pages and paid heed to the other things Marx said concerning, for example, the fact that capitalism technologises agriculture, that it reduces the agricultural population etc. But they never stopped to study what he said about the relationship between the human species and nature. (Llorente 2014, 185-188)

Hegel's substratum continued inhibiting an ecological Marxism because "acceptance of the model of advance on the bad side is, at any rate, hardly consistent with a programme of political ecology":

If things must advance on the bad side, one could say, we should let them get worse...I am sure this is not a full explanation, but I think it is likely that the reason for the scant attention paid to Marx's observations on political ecology has a great deal to do with the Hegelian element of his philosophy. Any useful continuation of the Marxist tradition must start by abandoning the Hegelian dialectical schema regarding the philosophy of History.

It is worth remembering that the same Hegelian foundation explains why Marx and Engels considered a waste of time trying to explore the future design of a communist society, or even a socialist transition. Following Hegel, they thought that history will tell. This teleological attitude ended up reinforcing what Sacristán called a "millennial," "eschatological" or "chiliastic" viewpoint of revolution, which has to be overcome to face the socio-ecological crisis of our time:

The main transformation of revolutionary thought suggested by ecological constraints involves abandoning the wait for the Last Judgement, abandoning utopianism and eschatology, and ridding oneself of millennialism. Millennialism is the belief that the Social Revolution is the peak of all time, an event after which all the tensions among people, and between people and nature, will be resolved...We must recognise that our natural capacities and needs are capable of expanding to the 
point of self-destruction. We must see that we are biologically the species of hubris, of original sin, of arrogance-the species of excess. (Llorente 2014, 188-189)

From this he drew an important political conclusion:

\begin{abstract}
[T] he revolutionary agent's action will have to be described in a manner that is much less Faustian and inspired more by the rules of conduct characteristic of the archaic tradition. So archaic that it can be summarised in one of the Delphos maxims: "Nothing in excess"...So, if this reflection is not completely off the mark, we ought to aim at an inversion of some of the values of the modern revolutionary tradition. (Llorente 2014, 191-192)
\end{abstract}

This led Sacristán to pose the key revolutionary question of our time in the first issue of Mientras Tanto in 1979: What society of associated producers or what Earth-friendly communities could be founded in a noisy chemical, pharmaceutical and radioactive dung heap? For an ecological Marxism free from Hegelian tethers, the first task is to ensure that a fair humankind can still be set up on a liveable Earth. If we want to give socialism a real chance, we must begin by placing the global ecological crisis in the foreground.

\title{
The Character of Sacristan's Ecological Marxism: A Final Remark
}

How could Sacristán start this ecological Marxism in the time and place he did? An answer in depth to this last question would require another article devoted to explaining his intellectual and political biography in detail. Yet it is worth finishing this one by sketching some traits. As John Bellamy Foster says when speaking about the big tragedy befallen to ecological Marxism after Bukharin's murder in 1938, Stalinism became an even greater barrier (2000, 243-244). For if Hegelianism had prevented a Marxist exploration on what socialism would actually look like, the task had per force to be undertaken once the time of revolution finally came along. The broken red-green thread stemming from Marx's ecological inklings was occasionally taken up by some authors directly committed to socialist revolutions, like Rosa Luxemburg and Otto Neurath (in the German Revolution of 19181919), Cristopher Caudwell (up to his death in the Spanish Civil War in 1937), and Nikolai Bukharin (in the Russian Revolution up to Stalinism).

Luxemburg's ([1913] 1964) idea of setting the capitalist dynamics in a never ending colonial expansion over different sorts of sustenance-oriented "natural economies," placed as an environment either underneath or outside capitalist frontiers, has been retaken by ecofeminism (Mies 1986; Mies and Shiva 1993). When Otto Neurath, the organizer of the Vienna Circle, was in charge of the office for central economic planning in the Soviet of Munich in 1918-1919, he raised a discussion on the ethical and ecological dilemmas posed by the allocation of non-renewable resources and pointed out the need of using several irreducible units of measurement to deal with this problem in economicstwo seminal contributions which allowed overcoming important shortcomings of the ill-fated Engels-Podolinsky debate, and have been later recovered by Alier (1987a, 206-2018) and O'Neill (2007). The intellectual and political evolution of Sacristán had many things in common with Neurath's ones. Owing to the double life, legal and clandestine, that Sacristán went through, and being expelled to the university many years by the Spanish dictatorial authorities, he could not find time to study Neurath in depth until the end of his life. When, at the request of Joan Martínez Alier, I asked Francisco Fernández Buey why Sacristán did not write anything about Neurath, he told me that he had commented to him: "This man did what I would have liked to do all my life, but I could not."

A short outline of Christopher Caudwell's original ideas on how the economic metabolism is mixed up with loving impulses to thread the social fabric of human society can be found in Edward P. Thompson book Persons \& Polemics (1994, 79-139). Caudwell's (1971) essays were translated into Spanish by Vicente Romano, a youth friend of Sacristán, and published in 1985-the same year Sacristán died. Nikolai Bukharin's most influential book, Historical Materialism ([1921] 2011), recovered Marx's ecological inklings on social metabolism trying to develop them using energy accounts again without relying on Podolinsky's previous attempt. Martínez Alier included him among the precursors of Ecological Economics (1987a, 225-228). Sacristán (1983, 275) had posed in 1972 an intriguing question in his prologue to the Spanish translation of a biography of this 
Bolshevik leader: "What Bukharin did, and what he said, over the almost ten years after his final defeat and his murder?" Now we know that Bukharin's ([1938] 2005) interest in the metabolic coevolution between societies and nature emerged once more as the central issue of a book he wrote in the Lubyanka prison in Moscow, while awaiting execution by the Stalinist minions.

All the above-mentioned attempts to rethread Marx's ecological inklings were crushed under the Stalinist slab, once the Soviet Revolution was turned into an industrial revolution and the official Marxism of the USSR became a state ideology to legitimate the task of fostering a centrally planned economic growth driven by a tyranny-as Sacristán explained in a 1978 lecture on Stalinism (Llorente 2014, 220-229). When Sacristán was chatting in confidence with his wife Giulia Adinolfi, their daughter Vera, or some closest friends, he used to refer to the political rulers of the USSR with the name of "Rusianos," a Spanish contraction of "Russians" and "Prussians" that highlighted the militarist character of the dictatorship exerted in that sort of war socialism (López Arnal and Mir García 2015, 294).

The restart of a Marxist political ecology after the inhibitions of the Hegelian-dialectic fog, and after the inward repression of the Stalinist vulgate, necessarily meant a new beginning. An indispensable condition was to adopt a politically belligerent stance against Stalinism. This was not enough, though, as shown by many anti-Stalinists who approached socialdemocracy instead of political ecology during the second half of the $20^{\text {th }}$ century. Hegelianism also had to be overcome, which required a much freer and radical rethinking of Marxism. Manuel Sacristán became a communist when he had already a good training in logic and philosophy of science of the time, very far away from Hegelianism. He thought, contrary to Hegel, that "not all that is real is rational-almost anything, indeed" (Sacristán 1987, 126). In a press interview Sacristán stressed in 1979 the link that existed between doing away with Hegelian legacies and recovering a revolutionary stand from a political ecology viewpoint:

I am not saying this to shock anyone, but revolutionary ideas ought to be recovered. By the same token, the Hegelian "negation of the negation" also has to be forgotten once and for all-that is, the idea of reaching the worst state in order to improve. (Fernández Buey and López Arnal 2004, 121)

In 1956 he was offered a post in the Department of Mathematical Logic and Basic Research at the University of Münster, Germany, which he turned down to join the PCE in Paris and return to Spain to take an active part in the clandestine fight against Franco's dictatorship (Llorente 2014, 2). As a matter of fact, after breaking in 1946 with his youthful membership to the Falangist student organization, and under a deep influence by his readings of Simone Weil, Sacristán first tried to connect with the Spanish anarchists. The libertarian person whom he asked for a connection with the underground movement said to him that if he wanted to fight against Franco's regime, he would better contact the communists because they were the only ones who had a good resistance network inside Spain (López Arnal and Mir García 2015, 258-259). In 1954-1956 his roommate at the University of Münster, the Ph.D. student Ettore Casari, was already a member of the Italian Communist Party. He helped Sacristán get in contact with German communists and then with the leaders of the PCE exiled in Paris. No doubt he was troubled with the violent repression of the Hungarian revolt in 1956 and he had an unpleasant discussion on that issue with the French Marxist historian Pierre Vilar. But knowing that the only workers' active resistance under Franco's regime was the one organized by the PCE, and the PSUC in Catalonia, he decided to join them.

In 1957 Sacristán married Giulia Adinolfi, an Italian communist and graduated in Philology specialized in Hispanic Studies in Naples. This meant another chance for him to start an academic career in a democratic country. But both decided to come back to Spain and become members of a late anti-fascist resistance. In my view, this helps to explain why their Marxism was so intellectually free. Political engagement had nothing to do for them with an uncritical adhesion to any abstract ideology. More than anything else, it was a commitment to place and the people with whom to fight for freedom. Unlike other Marxists who were or are still scared that revising the postulates of the tradition always entails a risk of adulterating the principles, they adopted a clear-cut distinction between values, knowledge and programmatic formulations within the Marxist tradition. They thought that the only things nobody can adulterate of a political tradition are its values-at least not without immediately leaving it. For any other component, the fear of adulteration ends up becoming 
a barrier to keep a tradition alive. Knowledge changes, evolves and improves. If the political tradition intends to base the fulfillment of its values in the better available knowledge of the time-as is the case with Marxism-it has to remain open to revising any knowledge-based formulation. This involves a permanent reassessment of its programs and ways of acting, as long as they combine an ever-changing base of knowledge with its own permanent values.

Sacristán considered himself more a communist than a Marxist or anything else, placing at the foreground the political and moral choices made in terms of values and life decisions. He left the PCE-PSUC leadership in 1969 and the parties themselves in 1979, when he considered them to have betrayed the values of socialism and communism-not to mention of ecological sustainability. When he approached the new social movements during the last years of his life, Sacristán recovered some anarchist sprouts of his youth (Fernández Buey and López Arnal 2004, 191-197). Giulia Adinolfi developed a feminist approach looking at women as a political entity. She thought women were able to come to terms with their own subculture critically and to make genuine contributions to collective emancipation (Rossi et al. 2005, 15-89). Adinolfi played a crucial role in pushing Sacristán and a group of friends to start publishing Mientras Tanto as a red-green-violet journal up to her early death in 1980. Both Sacristán and Adinolfi were able to set forth in Barcelona just the kind of free-thinking Marxism required to connect with political ecology and feminism in the last quarter of the $20^{\text {th }}$ century.

\section{Acknowledgement}

The author wants to thank for the help given by Joan Martínez Alier, Renzo Llorente and Elena Grau to ameliorate the earlier drafts of this article, and to the anonymous reviewers in improving this last version. Francisco Fernández Buey also encouraged me to complete and publish it, before he passed away in 2012. Sacristán's texts are quoted according to Renzo Llorente's translation into English, except when they were not included in the volume The Marxism of Manuel Sacristán Llorente edited in 2014. In the latter case the translation is by George Ritter and the author. I wish to thank CNS' Kris Forkasiewicz for the thorough revision of the English in the article.

\section{Funding}

This work was supported by the Spanish research project [grant number HAR201238920-C02-02]; the Social Sciences and Humanities Research Council of Canada [the Partnership grant number 895-2011-1020]; the Centre d'Estudis Antoni de Capmany d’Economia i Història Econòmica at the University of Barcelona.

\section{ORCID}

Enric Tello http://orcid.org/0000-0002-4970-1524

\section{References}

Adinolfi, Giulia. 1980. “Esquema sobre el trabajo doméstico.” Mientras Tanto 3: 19-21.

Antunes, Carlos, Pierre Juquin, Penny Kemp, Isabelle Stengers, Wilfried Telkämper, and Wolf, Frieder Otto. 1990. "Manifiesto ecosocialista." Mientras Tanto 41: 59-171.

Bahro, Rudolf. 1977. Die Alternative. Berlin: Spiegel [La Alternativa, Barcelona: Materiales, 1978].

Bahro, Rudolf. 1978. "Contribución a la crítica del socialismo real." Materiales 10: 95-120; and Materiales 11: $103-126$.

Barrett, Samuel M., ed. 1906. Geronimo's Story of His Life. New York: Duffield and Co. [Gerónimo. Historia de su vida. Barcelona: Grijalbo, 1975].

Bay Area Group. 1978. Acerca de 'La crisis fiscal del Estado’ de James O’Connor. Materiales 10: 123-135.

Boulding, Kenneth E. 1978. Ecodynamics: A New Theory of Societal Evolution. Beverly Hills, CA: Sage.

Bukharin, Nikolai. [1938] 2005. Philosophical Arabesques. New York: Monthly Review Press.

Bukharin, Nikolai. [1921] 2011. Historical Materialism-A System of Sociology. New York: Routledge.

Burkett, Paul, and John Bellamy Foster. 2006. "Metabolism, Energy, and Entropy in Marx's Critique of Political Economy: Beyond the Podolinsky Myth.” Theory and Society 35: 109-156. 
Capella, Juan-Ramon. 2005. La práctica de Manuel Sacristán. Una biografía política. Madrid: Trotta.

Caudwell, Christopher. 1971. Studies and Further Studies in a Dying Culture. New York: Monthly Review Press.

Commoner, Barry. 1970. Science and Survival. New York: Viking.

Commoner, Barry. 1971. The Closing Circle. London: Jonathan Cape.

d'Eaubonne, Françoise. 2000. "What Could an Ecofeminist Society Be?" Ethics and the Environment 4 (2): 179-184 [English excerpts of the book Écologie, féminisme: révolution ou mutation? Paris: Éditions A.T.P., 1978].

Engel-Di Mauro, Salvatore. 2014. Ecology, Soils and the Left. An Eco-Social Approach. New York: Palgrave MacMillan.

Fernández Buey, Francisco, and Salvador López Arnal, eds. 2004. De la primavera de Praga al marxismo ecologista. Entrevistas con Manuel Sacristán Luzón. Madrid: Libros de la Catarata.

Foster, John Bellamy. 2000. Marx's Ecology: Materialism and Nature. New York: Monthly Review Press.

Foster, John Bellamy, and Paul Burkett. 2004. "Ecological Economics and Classical Marxism. The 'Podolinsky Business' Reconsidered." Organization and Environment 17 (1): 32-60.

Foster, John Bellamy, and Paul Burkett. 2008a. "Classical Marxism and the Second Law of Thermodynamics: Marx/Engels, the Heat Death of the Universe Hypothesis, and the Origins of Ecological Economics." Organization and Environment 21(1): 3-37.

Foster, John Bellamy, and Paul Burkett. 2008b. "The Podolinsky Myth: An Obituary. Introduction to 'Human Labour and Unity of Force' by Sergei Podolinsky." Historical Materialism 16: 115-161.

Georgescu-Roegen, Nicholas. 1971. The Entropy Law and the Economic Process. Cambridge, MA: Harvard University Press.

Giampietro, Mario, Kozo Mayumi, and Alevgul H. Sorman. 2012. The Metabolic Pattern of Societies: Where Economists Fall Short. London: Routledge.

González de Molina, Manuel, and Víctor Toledo. 2014. The Social Metabolism. A Socio-Ecological Theory of Historical Change. Dordrecht: Springer.

Gorz, André. 1975. Écologie Politique. Paris: Galilée.

Harich, Wolgang. 1977. Kommunismus ohne Wachstum? Berlin: Rowohlt [¿Comunismo sin crecimiento? Barcelona: Materiales, 1978].

Ho, Mae-Wan, and Robert U. Ulanowicz. 2005. “Sustainable Systems as Organisms?” BioSystems 82: 39-51.

Kovel, Joel, and Michael Löwy. 2001. "Ecosocialist Manifesto." http://ecosocialistnetwork.org/Wordpress/wpcontent/uploads/2012/03/Manifesto-1-en.pdf.

Lacalle, Daniel, Joan Martínez Alier, and Manuel Sacristán. 1978. “Cinco cartas sobre 'eurocomunismo', marxismo y anarquismo." Materiales 8: 119-144.

Llorente, Renzo, ed. 2014. The Marxism of Manuel Sacristán. From Communism to the New Social Movements. Boston: Brill.

López Arnal, Salvador, and Jordi Mir García, eds. 2015. Francisco Fernández Buey. Sobre Manuel Sacristán. Barcelona: El Viejo Topo.

Löwy, Michael. 2013. “¿Qué es el ecosocialismo?” http://www.democraciasocialista.org/?p=1526.

Luxemburg, Rosa. [1913] 1964. The Accumulation of Capital. New York: Monthly Review Press.

Martínez Alier, Joan. 1980. "La crisis energética y la agricultura moderna." Boletín de Información sobre Energía Nuclear 13: 11-16.

Martínez Alier, Joan. 1982. "L'anàlisi energètica i la ciència econòmica." Mientras Tanto 12: 47-57.

Martínez Alier, Joan. 1984. L'ecologisme i l'economia. Barcelona: Edicions 62.

Martínez Alier, Joan. 1985a. "Réplica a mis críticos." Mientras Tanto 23: 37-43.

Martínez Alier, Joan. 1985b. "La base social del ecologismo de izquierda: ¿un neopopulismo ecológico?" Mientras Tanto 25: 21-28. 
Martínez Alier, Joan. 1987a. Ecological Economics: Energy, Environment and Society. Oxford: Basil Blackwell.

Martínez Alier, Joan. 1987b. "Utopismo ecológico: Popper-Lynkeus y Ballod-Atlanticus." Mientras Tanto 33: 71-85.

Martínez Alier, Joan. 1988. “El marxismo y la economía ecológica.” Mientras Tanto 35: 127-147.

Martínez Alier, Joan. 1991. La ecología y la economía. México: Fondo de Cultura Económica.

Martínez Alier, Joan. 2007. "Economía ecológica y ecología política." In El legado de un maestro, edited by Salvador López Arnal and Iñaki Vázquez, 209-222. Madrid: Fundación de Investigaciones Marxistas.

Martínez Alier, Joan, and Alberto Flores Galindo. 1988. "Agricultura, alimentación y medio ambiente en Perú." Mientras Tanto 34: 79-89.

Martínez Alier, Joan, and José Manuel Naredo. 1982. "A Marxist Precursor of Energy Economics: Podolinsky." The Journal of Peasant Studies 9(2): 207-224. doi:10.1080/03066158208438162.

Marx, Karl. [1867] 1996. Capital: A Critique of Political Economy, Vol. 1. In Marx and Engels Collected Works, Vol. 35. New York: International Publishers.

Marull, Joan, Carme Font, Roc Padró, Enric Tello, and Andrea Panazzolo. 2016. "Energy-Landscape Integrated Analysis: A Proposal for Measuring Complexity in Internal Agroecosystem Processes (Barcelona Metropolitan Region, 1860-2000)." Ecological Indicators 66: 30-46.

Mies, Maria. 1986. Patriarchy \& Accumulation on a World Scale. New York: Zed Books.

Mies, Maria, and Vandana Shiva. 1993. Ecofeminism. New York: Zed Books.

O’Neill, John. 2007. "Pluralism and Economic Institutions." In Neurath's Economics in Context, edited by Elisabeth Nemeth, Stefan W. Schmitz, and Thomas E. Uebel, 77-100. Dordrecht: Vienna Circle Institute Yearbook/Springer.

Pérez, Alejandro. 1980. "Documentos sobre el congreso programático del partido verde alemán." Mientras Tanto 2: 33-43.

Podolinsky, Sergei. [1880-1883] 2008. "Human Labour and Unity of Force." Historical Materialism 16(1): $163-183$.

Rossi, Rosa, Pérez-Vidal, Carmela, Lentini, Rosa, Vilaginés, Carme, Fibla, Pilar, Pérez-Vidal, Alejandro, and Elena Grau-Biosca. 2005. "Dimensiones de una ausencia. Memoria de Giulia Adinolfi." Mientras Tanto 94: 15-89.

Sacristán, Manuel. 1981. "Una conversación con Wolgang Harich y Manuel Sacristán (1979)." Mientras Tanto 1981: 33-52.

Sacristán, Manuel. 1983. Sobre Marx y marxismo. Panfletos y materiales, Vol. I. Barcelona: Icaria.

Sacristán, Manuel. 1984. "Sobre los problemas presentemente percibidos en la relación entre la sociedad y la naturaleza y sus consecuencias en la filosofía de las ciencias sociales. Un esquema de discusión.” In Papeles de filosofía. Panfletos y materiales, Vol. 3. Barcelona: Icaria.

Sacristán, Manuel. 1985. Intervenciones políticas. Panfletos y materiales, Vol. III. Barcelona: Icaria.

Sacristán, Manuel. 1986. "Changing the Nature of Politics." Journal of European Nuclear Disarmament 19: 21-22.

Sacristán, Manuel. 1987. Pacifismo, ecología y política alternativa. Barcelona: Icaria.

Sacristán, Manuel. 1992. "Political Ecological Considerations in Marx." Capitalism Nature Socialism 3 (1): 37-48.

Tanuro, Daniel. 2010. "Marxism, Energy and Ecology: The Moment of Truth." Capitalism, Nature, Socialism 21(4): 89-101.

Tello, Enric. 2003. "Leer a Manuel Sacristán en el crisol de un nuevo comienzo.” Mientras Tanto 89: 61-101.

Tello, Enric. 2007. “Manuel Sacristán (1925-1985): ¿El primer marxista ecológico post-stalinista?” In El legado de un maestro, edited by Salvador López Arnal and Iñaki Vázquez, 291-303. Madrid: Fundación de Investigaciones Marxistas.

Tello, Enric, Elena Galán, Vera Sacristán, Geoff Cunfer, Gloria I. Guzmán-Casado, Manuel González de Molina, Krausmann, Fridolin et al. 2016. "Opening the Black Box of Energy Throughput in Farm Systems: A Decomposition Analysis Between the Energy Returns to External Inputs, Internal 
Biomass Reuses and Total Inputs Consumed (the Vallès County, Catalonia, c.1860 and 1999)." Ecological Economics 121: 160-174.

Thompson, Edward P. 1994. Persons \& Polemics. London: Merlin Press.

Vernadsky, Vladimir. 2007. Geochemistry and the Biosphere. Santa Fe, NM: Synergetic Press. 